\title{
An efficient protocol for in vitro regeneration in java citronella (Cymbopogon winterianus) through callus
}

\author{
SANTOSH J. GAHUKAR, SNEHAL M. BANSOD AND AMRAPALI A. AKHARE*
}

Biotechnology Centre, Dr. Panjabrao Deshmukh Krishi Vidyapeeth, AKOLA (M.S.) INDIA

Email : atulkhare@yahoo.com

The reproducible indirect in vitro regeneration system through callus was developed in Java citronella (Cymbopogon winterianus) for genotype Bio-13. Tender leaves from the lower portion of the citronella culms were used as explants. The MS medium supplemented with different concentrations of 2, 4-D (1.0, 3.0, 5.0 and $7.0 \mathrm{mg} / \mathrm{l})$ alone or in combination of BAP $(0.2,0.4$ and $0.6 \mathrm{mg} / \mathrm{l})$ were used for callus induction. For regeneration of plantlets MS media with different concentrations of BAP $(0.1,0.2,0.3$ and $0.5 \mathrm{mg} / \mathrm{l})$ alone or in combination with NAA $(0.1,0.2$ and $0.3 \mathrm{mg} / \mathrm{l})$ were employed. The induction of organogenic callus was highest in medium containing $5 \mathrm{mg} / 12$, 4-D with 99.66 per cent explants showing callus formation. At higher concentration of BAP $(0.5 \mathrm{mg} / \mathrm{l})$ shoots were initiated rapidly from the callus within 13 days. The root formation response was best in MS medium containing $3.0 \mathrm{mg} / 1$ NAA (83.33\% shoots formed roots within 25 to 30 days). The regenerated plantlets transferred to autoclaved garden soil, soilrite and sand in 1:1:1 proportion and irrigated with half strength MS solution showed 85 per cent survival rate after three weeks.

Key words : Callus, In-vitro regeneration, Aromatic grass, Citronella, Somaclonal variation

How to cite this paper : Gahukar, Santosh J., Bansod, Snehal M. and Akhare, Amrapali A. (2014). An efficient protocol for in vitro regeneration in java citronella (Cymbopogon winterianus) through callus. Asian J. Bio. Sci., 9 (2) : 267-272. 